\title{
Flexural Behavior Of R/C Beams With Externally Bonded Gfrp Sheets
}

\author{
Bayar J. Al-Sulayfani \\ Professor
}

\author{
Ashtar S. Al-Luhybi \\ Assistant Lecturer
}

\section{University of mosul/College of engineering/civil engineering department}

\begin{abstract}
During the latest decades there has been a significant increase in using FRP (Fiber Reinforced Polymers) as a main material for external reinforcement in the construction industry.Externally bonded FRP sheets have been used to increase moment capacity of flexural members and to improve confinement in compression members. This paper summarizes the result of experimental and analytical studies on the flexural strengthening of reinforced concrete beams by external bonding of glass fiber reinforced polymer sheets to the tension face of the beam. Four beams, three with different thickness of GFRP sheets and one without GFRP sheets were tested using third-point loading over a span of $900 \mathrm{~mm}$. The tests were carried out under load control. The results indicate that the flexural strength of the beams increased significantly as the thickness of the sheet increased. Analytical study using a computer program based on strain compatibility is presented to predict the ultimate strength and load-deflection behavior of the beams. When the experimental results were compared with theoretical ones, good acceptable agreement was obtained which make it possible to consider and recommended this model in the design.
\end{abstract}

Keyword: Analytical Study, Flexural Behavior, GFRPSheets, Strengthening.

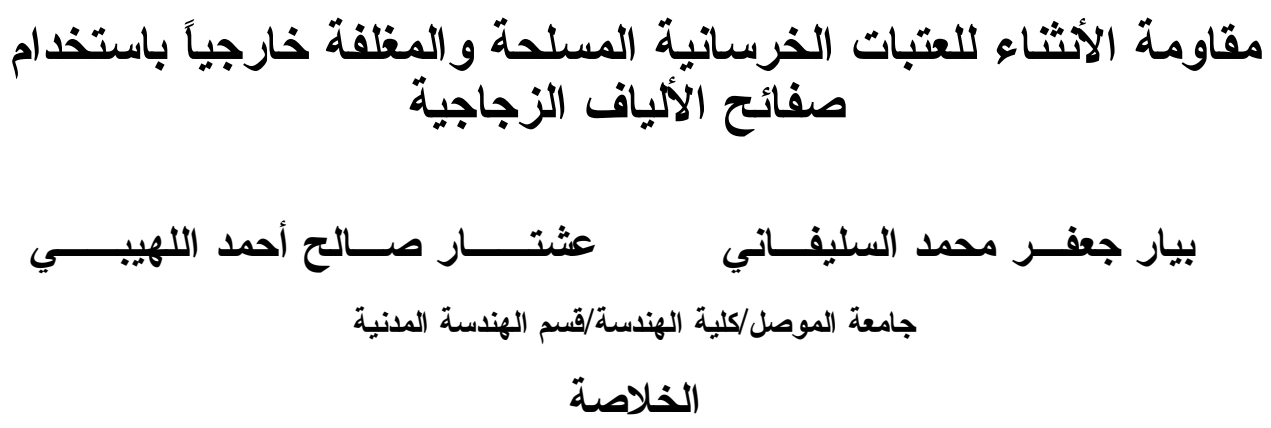

زاد أستخدام ألياف البوليمر كمادة رئيسة في التسليح الخارجي للمنشآت الصناعية بشكل ملحوظ خلال العقــود التهاء

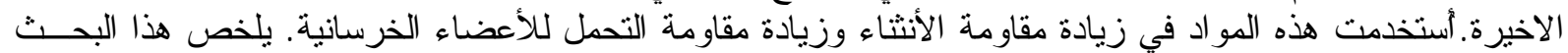

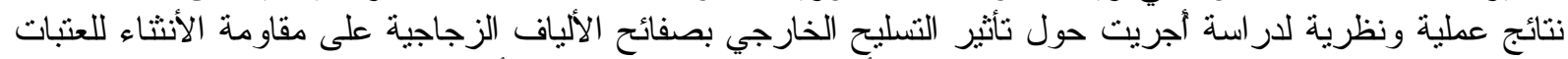

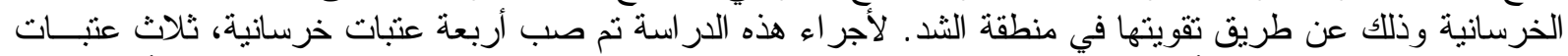

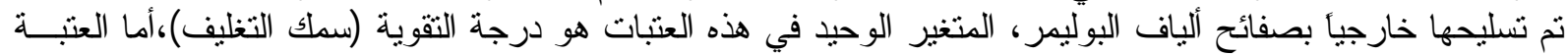

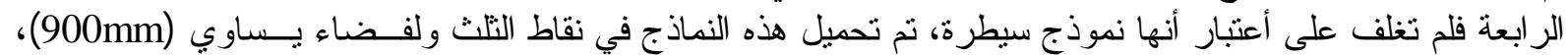

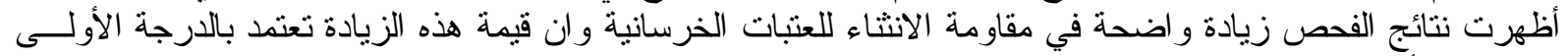

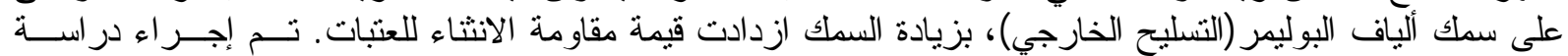

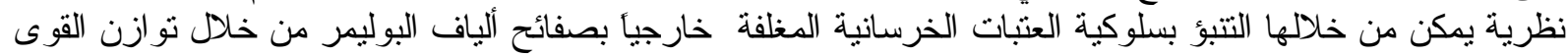

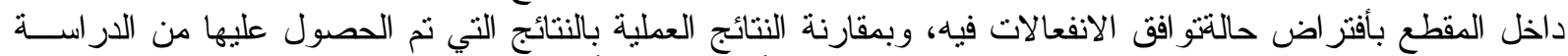
النظرية يمكن القول بأن هناك ثو افق جيد ومقبول و الذي على أساسه يمكن أعتماد هذا النموذج في التصميم. 


\begin{abstract}
Al-Rafidain Engineering $\quad$ Vol.17 $\quad$ No.6 $\quad$ Dec. 2009
Introduction :

The use of externally bonded fiber reinforced polymer (FRP) to strengthen reinforced concrete $(\mathrm{R} / \mathrm{C})$ structures is increasingly becoming popular retrofit technique. The light weight and formability of FRP reinforcement makes these systems non-corrosive, nonmagnetic, and generally resistant to chemicals, they are an excellent option for external reinforcement (1).Glass fiber reinforced polymer (GFRP), like carbon fiber reinforced polymer(CFRP), are more attractive than steel for use as external reinforcement. Strengthening with externally bonded FRP sheets has been shown to be applicable to many types of R/C structures. Currently, this method has been implemented to strengthen structures such as columns, beams, slabs, walls, chimneys, tunnels, silos(2), girders in structures such as bridges, parking decks, and building. Tests on beams with a bonded GFRP plate $(3,4)$ show that it can enhance the ultimate flexural strength considerably when the steel reinforcement ratio is much lower than the balanced steel ratio, and in most cases the concrete fails long before the GFRP plate reaches its ultimate load capacity. Several research studies have addressed the upgrade of reinforced concrete (RC) element using fiber-reinforced plastic (FRP) plates as a substitute for steel plates (4-8). The purpose of this paper is thus to enhance the understanding of the flexural behavior of reinforced concrete $(\mathrm{R} / \mathrm{C})$ beams strengthened externally by GFRP Sheets, and to develop clearer picture of the role and effectiveness of the GFRP sheets in the structural performance of the strengthened beam.
\end{abstract}

\title{
Experimental program properties of materials:
}

Concrete: Concrete with compressive strength of $36 \mathrm{MPa}$ is specified for all the concrete beams. Ordinary Portland cement, locally available sand and gravel in Mosul city with maximum aggregate size of $(19 \mathrm{~mm})$ were used.

GFRP Sheets and epoxy adhesive: The ultimate tensile stress $\left(\sigma_{f u}\right)$

and Young's modulus $\left(\mathrm{E}_{f}\right)$ of GFRP Sheet is determined by conducting tension tests on coupons cut from the sheet. The Young's modulus and the ultimate tensile stress of GFRP Sheet are calculated from load/strain curves and presented in Table (1). The properties of epoxy used for bonding the GFRP sheet are also presented in Table (1).

Test Specimens: Four R/C beams (1000mm-long) having cross-sectional dimensions of $150 \times 150 \mathrm{~mm}$ (Fig.1) were used. The beams were made from the same batch. Control specimens were cast with concrete from the same batch for compressive strength, Modulus of elasticity, tensile splitting, and modulus of rupture. Each concrete beam is reinforced with two $10 \mathrm{~mm}$ diameter steel bars for tension along with $6 \mathrm{~mm}$ diameter steel closed stirrups at a spacing of 55mm center-to-center for shear reinforcement. The internal strain was measured with two handmade gage. The hand made gages consisted of a electronic strain gage with $6 \mathrm{~mm}$ long placed on the middle of rebar. A hand held grinder was used to smoothed out a two inch section were the gage was attached. The devices are shown in Figure (2). The strain was measured by Model 1300 Gauge Installation Tester. The effective span of all the beams is kept as $900 \mathrm{~mm}$. The concrete control beam is designated as RB1-0, three beams wrapped with different levels by changing the thickness of GFRP sheet. One beam wrapped with one layer of GFRP Sheet (RB2-1-B), the second beam wrapped with two layers of GFRP Sheet (RB3-2-B) and the third beam wrapped with three layers of GFRP Sheet (RB4-3-B). The details of the beams are presented in Table (2). 
Table (1): Properties of GFRP Sheets, Epoxy and Reinforcement

\begin{tabular}{|c|c|c|c|c|}
\hline \multirow[b]{2}{*}{ Material } & \multicolumn{4}{|l|}{ Properties } \\
\hline & $\begin{array}{l}\text { Ultimate Tensile } \\
\text { Stress }(\mathrm{MPa})\end{array}$ & $\begin{array}{l}\text { Youngs Modulus } \\
(\mathrm{MPa})\end{array}$ & \multicolumn{2}{|c|}{ Ultimate Strain } \\
\hline GFRP Sheet & 108 & $30 \times 10^{3}$ & \multicolumn{2}{|l|}{$2 \%$} \\
\hline \multirow[b]{2}{*}{ Material } & \multicolumn{4}{|l|}{ Properties } \\
\hline & $\begin{array}{l}\text { Tensile Strength } \\
\text { (MPa) }\end{array}$ & $\begin{array}{l}\text { Flexureal } \\
\text { Strength (MPa) }\end{array}$ & $\begin{array}{l}\text { Density } \\
\mathrm{Kg} / \mathrm{m}^{3}\end{array}$ & $\begin{array}{l}\text { Compressive } \\
\text { Strength (MPa) }\end{array}$ \\
\hline $\begin{array}{l}\text { Epoxy } \\
\text { Adhesive }\end{array}$ & 29 & 91 & 1060 & 83 \\
\hline Material & \multicolumn{4}{|l|}{ Properties } \\
\hline Steel & \multicolumn{2}{|c|}{ Yield Strength(MPa) } & \multicolumn{2}{|c|}{ Ultimate Strength(MPa) } \\
\hline $6 \mathrm{~mm}$ & \multicolumn{2}{|l|}{423} & \multicolumn{2}{|l|}{550} \\
\hline $10 \mathrm{~mm}$ & \multicolumn{2}{|l|}{627} & \multicolumn{2}{|l|}{752} \\
\hline
\end{tabular}

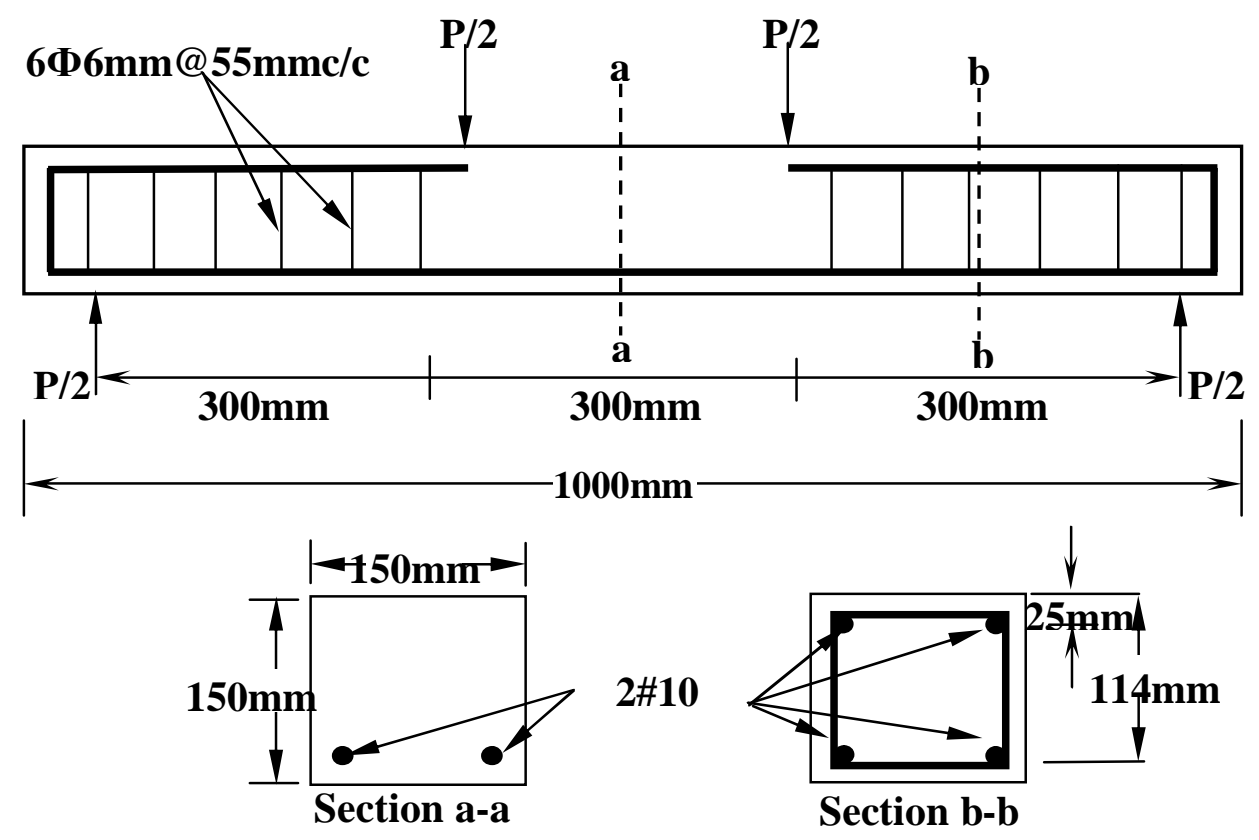

Figure (1): Test Beam Geometry

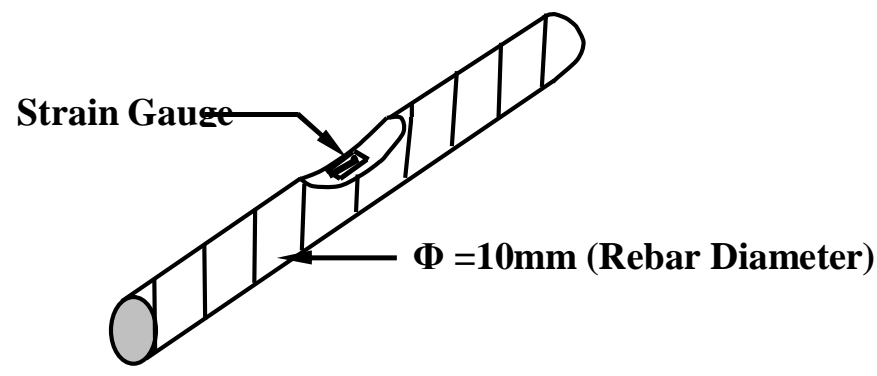

Figure (2): Homemade Internal Strain Gage 


\section{$\begin{array}{llll}\text { Al-Rafidain Engineering } & \text { Vol.17 } & \text { No.6 } & \text { Dec. } 2009\end{array}$}

Table (2): Test Specimens

\begin{tabular}{|c|c|c|c|c|c|c|c|c|}
\hline \multirow[b]{2}{*}{ Specimen } & \multicolumn{3}{|c|}{ Beam size } & \multirow[b]{2}{*}{$\begin{array}{c}\text { Effective } \\
\text { Span } \\
(\mathrm{mm})\end{array}$} & \multicolumn{4}{|c|}{ Strengthening Details } \\
\hline & $\begin{array}{c}1 \\
(\mathrm{~mm})\end{array}$ & $\begin{array}{c}\mathrm{B} \\
(\mathrm{mm})\end{array}$ & $\begin{array}{c}\mathrm{h} \\
(\mathrm{mm})\end{array}$ & & $\begin{array}{l}\text { No.of } \\
\text { GFRP } \\
\text { Sheet }\end{array}$ & $\begin{array}{c}\text { Length } \\
(\mathrm{mm})\end{array}$ & $\begin{array}{l}\text { Width } \\
(\mathrm{mm})\end{array}$ & $\begin{array}{c}\text { Thickness } \\
\text { (mm) }\end{array}$ \\
\hline RB1-0 & 1000 & 150 & 150 & 900 & 0 & - & - & - \\
\hline RB2-1-B & 1000 & 150 & 150 & 900 & 1 & 840 & 150 & 0.5 \\
\hline RB3-2-B & 1000 & 150 & 150 & 900 & 2 & 840 & 150 & 1.12 \\
\hline RB4-3-B & 1000 & 150 & 150 & 900 & 3 & 840 & 150 & 1.61 \\
\hline
\end{tabular}

Preparation and Curing : Prior to applying adhesive the bonding surface of the concrete beam is made rough by scarifying it with a toothed grinder and cleaning it with an air blower. All beams were completely dried before the epoxy was applied. The epoxy system consists of two parts, resin and hardener, mixed in the ratio of 3:1. The epoxy system was thoroughly hand mixed for at least 5 minutes. at room temperature. A thin layer of epoxy was applied to the concrete surface using paint roller. A GFRP saturated with epoxy sheet was then applied directly on the surface. Special attention was taken to ensure that there were no voids between the GFRP sheet and concrete surface, and the excess epoxy was squeezed out along the edges of the GFRP sheet, assuring complete epoxy coverage. After the application of the first layer of the GFRP sheet, a second layer of epoxy was applied on the surface of the first layer to allow the adhesion of the second layer of the GFRP sheet. Finally a last layer of epoxy was applied on the surface of the wrapped beam. The surfaces were then kept bonded together under pressure using mechanical clamp until the adhesive had cured. The time gap between the GFRP sheets bonding and the beam test was at least 7 days.

\section{Analytical Study:}

The purpose of this theoretical study is to develop a model that accurately predicts the flexural behavior of reinforced concrete beams (RB2-1-B), (RB3-2-B) and (RB4-3-B) strengthened with GFRP sheets. An iterative method is used in which increases the strain in the top compression fiber of the concrete is increased until the concrete crushes, tensile steel ruptures, or the FRP sheet ruptures. The following model is based on derivation presented by Saadatmanesh and Ehsani (9). It employs strain compatibility, force equilibrium, using the following assumptions:

1. Plane sections before deflection remain plane after deflection.

2. No Shear deformation.

3. Perfect bond between different materials.

The Stress-Strain curve for concrete is approximated using Al-Sulayfani (10)curve based on unique function shown schematically in Figure (3).

$$
\begin{array}{r}
\ldots . .(1) \sigma_{c}=\frac{A \bar{\varepsilon}}{\left(\bar{\varepsilon}^{3}+B \bar{\varepsilon}^{2}+C \bar{\varepsilon}+D\right)^{x}} \times f_{c}^{\prime} \\
\ldots \ldots \text { (2) } \bar{\varepsilon}=\frac{\varepsilon_{\mathrm{cc}}}{\varepsilon_{\mathrm{o}}}
\end{array}
$$

where, $\sigma c=$ compressive stress of concrete.

$f_{c^{\prime}}=$ the maximum compressive stress of concrete

$\varepsilon_{c^{c}}=$ concrete strain at any given point

$\bar{\varepsilon}=$ normalized strain at maximum compressive strength of concrete

$\varepsilon_{0}=$ the strain at the maximum compressive stress of concrete,

and is defined as: 


$$
\varepsilon_{o}=\left(0.85 \times\left(f_{c}^{\prime}\right)^{0.246}\right) \times 10^{-3}
$$

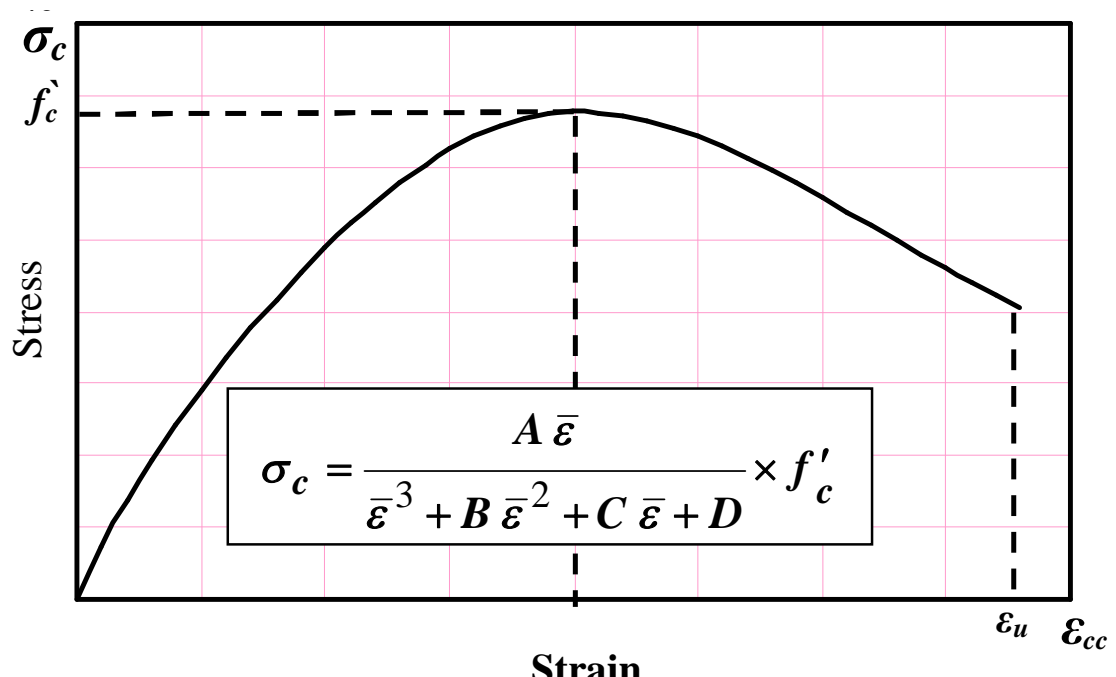

Figure (3): Schematic of concrete stress-strain behavior Developed Al-Sulayfani [10]

A,B,C,and D are constants can be evaluated by using the curves shown in figure(4).

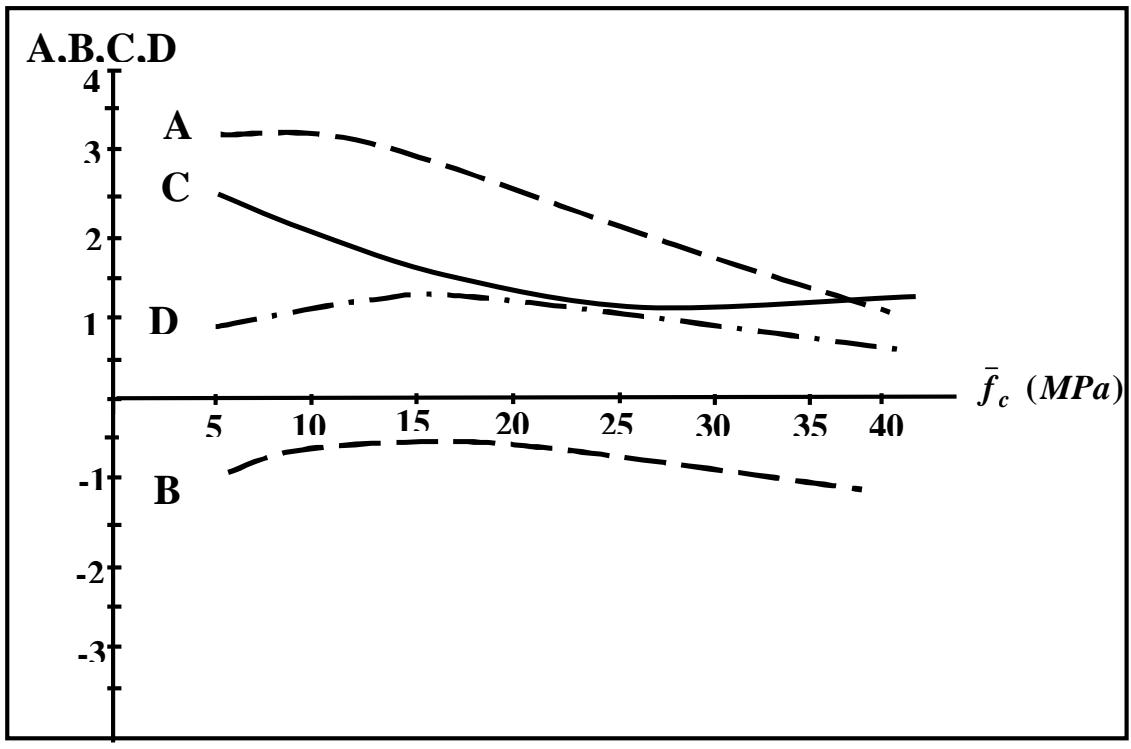

Figure (4): A,B,C,and D in compressive case(10)

For this model, a maximum concrete strain of (0.003) was used in the model developed for this research. The steel is assumed to exhibit a bilinear stress-strain behavior. A post yield modulus equal to 1.5 percent of the initial elastic modulus was used (10). The stress-strain curve for the reinforcing steel was simplified as shown in Figure(5). The stressstrain curve for the GFRP was determined experimentally as discussed in paragraph(2-1-2), it exhibit a bilinear stress-strain behavior as shown in figure(6). The following equations for the stresses of the GFRP and reinforcing steel, are obtained from their stress-strain behavior: 


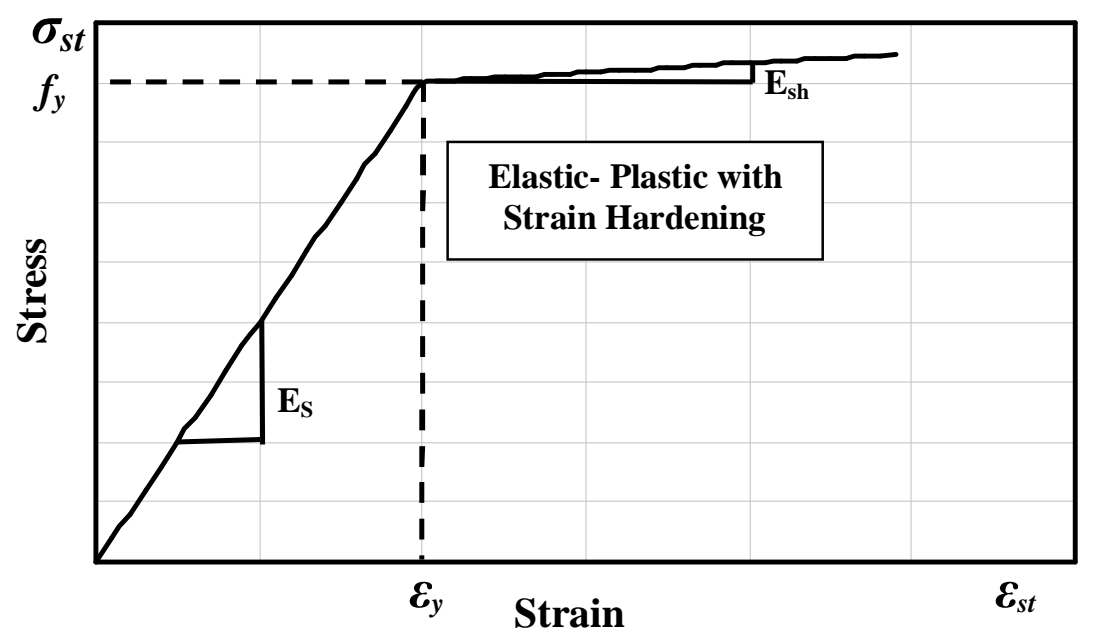

Figure (5): Theoretical Stress-Strain Plot of Steel Reinforcement

$$
\begin{array}{cc}
\sigma_{s t}=E_{s} \cdot \varepsilon_{s t} & \text { for } \varepsilon_{s t}<\varepsilon_{y} \\
\sigma_{s t}=f_{y}+E_{s h} \cdot\left(\varepsilon_{s t}-\varepsilon_{y}\right) & \text { for } \varepsilon_{s t} \geq \varepsilon_{y}
\end{array}
$$

where, $\varepsilon \mathrm{y}=$ the yield strain of the reinforcing steel

$\sigma_{\mathrm{St}}=$ the stress in the tension reinforcing steel

$E_{S}=$ the modulus of elasticity of the tension reinforcing steel

fy $=$ the yield stress of the reinforcing steel

Esh=Post yield modulus of steel reinforcement

$\varepsilon \mathrm{st}=$ Strain in tensile steel reinforcement.

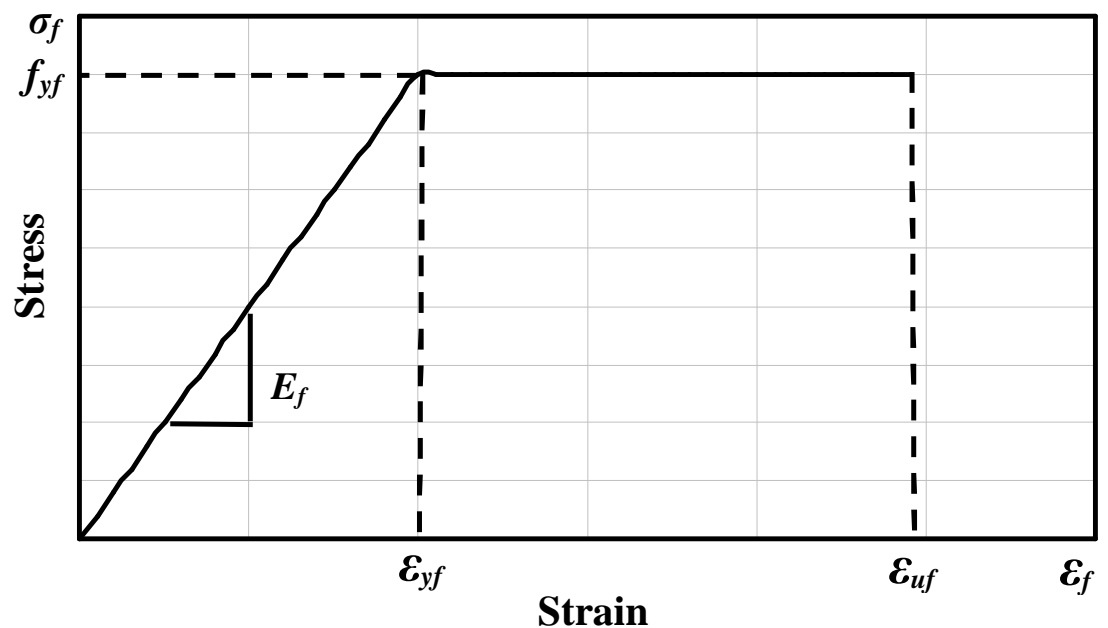

Figure (6): Average Stress-Strain Plot of GFRP

$$
\begin{array}{ll}
\sigma_{f}=E_{f} \cdot \varepsilon_{f} & \text { for } \varepsilon_{f}<\varepsilon_{y f} \\
\sigma_{f}=f_{y f} & \text { for } \varepsilon_{f} \geq \varepsilon_{y f}
\end{array}
$$

where, $\sigma_{\mathrm{f}}=$ the stress of the GFRP

$\mathrm{E}_{\mathrm{f}}=$ the modulus of elasticity of the GFRP

$\varepsilon_{\mathrm{f}}=$ strain in GFRP

$\mathrm{f}_{\mathrm{yf}}=$ maximum stress in GFRP 
The linear strain distribution through the cross section is shown in Figure(7). The concrete forces in tension, which are only used before the concrete cracks in tension, are not shown in Figure(7) for clarity. The strain in the compression steel, tensile steel, FRP strengthening sheet, and bottom tension fiber in the concrete can be found in terms of the strain in the concrete as follows

$$
\begin{gathered}
\varepsilon_{s t}=\varepsilon_{c c}\left[\frac{d_{s}-c}{c}\right]=\varepsilon_{c c}\left[\frac{d_{s}}{c}-1\right] \\
\varepsilon_{s c}=\varepsilon_{c c}\left[\frac{c-d^{\prime}}{c}\right]=\varepsilon_{c c}\left[1-\frac{d^{\prime}}{c}\right] \\
\varepsilon_{f}=\varepsilon_{c c}\left[\frac{d_{f-c}}{c}\right]=\varepsilon_{c c}\left[\frac{d}{c}-1\right] \\
\varepsilon_{c t}=\varepsilon_{c c}\left[\frac{h-c}{c}\right]=\varepsilon_{c c}\left[\frac{h}{c}-1\right]
\end{gathered}
$$

Where, $\varepsilon_{\mathrm{sc}}=$ Strain in compression steel reinforcement

$\varepsilon \mathrm{f}=$ Strain in FRP sheet

$\varepsilon c t=$ Tensile strain of concrete before cracking

$\mathrm{c}=$ Distance from neutral axis to the compression edge of member

$\mathrm{ds}=$ Distance from the centroid of the tension steel reinforcement to the compression edge of member.

$\mathrm{d}^{\prime}=$ Distance from the centroid of the compression steel reinforcement to the Compression edge of the member

$\mathrm{df}=$ from the centroid of the FRP strip to the compression edge of member

$\mathrm{h}=$ Height of the concrete beam

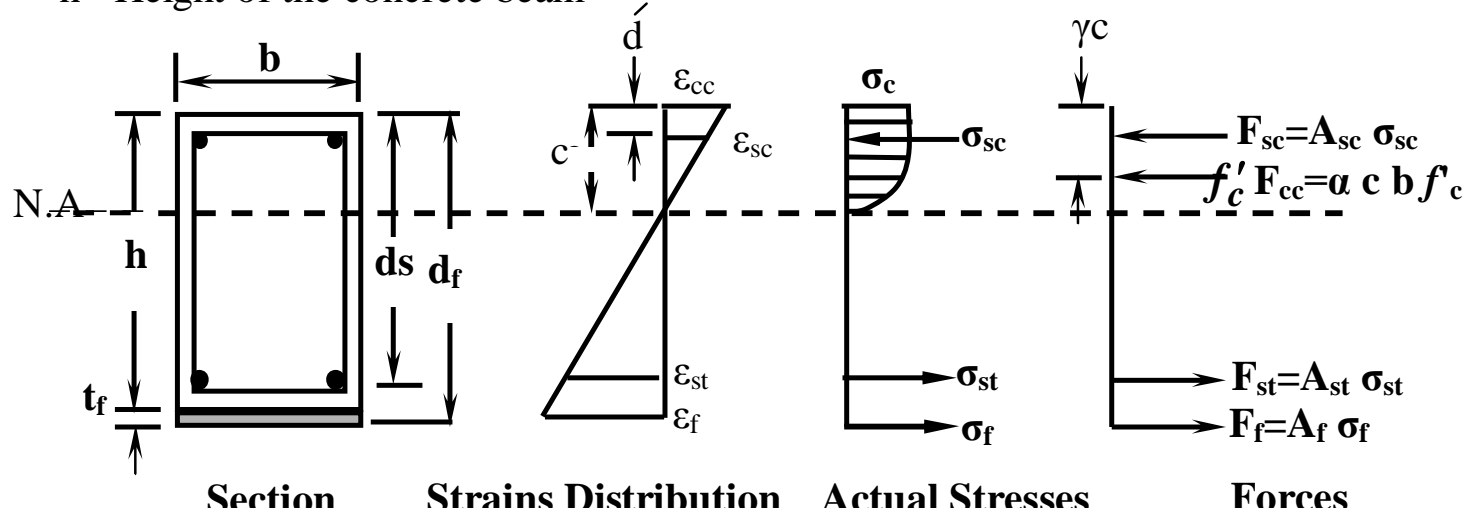

Figure (7): Strains, stresses, and forces used in the moment curvature model.

The concrete compressive force can be defined as follows

$\mathrm{F}_{\mathrm{cc}}=\alpha \mathrm{f}^{\prime}{ }_{\mathrm{c}} \mathrm{c} \mathrm{b}$

Where, $F_{c c}=$ the compressive force of concrete

$\alpha=$ the mean stress factor

$b=$ the width of the concrete beam 


\section{Al-Rafidain Engineering $\quad$ Vol.17 $\quad$ No.6 $\quad$ Dec. 2009}

The mean stress factor $(\alpha)$ converts the actual stress-strain relationship of concrete into a rectangular stress-strain equivalent. This parameter is calculated by integrating the area under the stress-strain curve with respect to the compressive strain of concrete as shown in Figure (8).The integration is equated to the mean stress factor as follows:

Area under stress-strain curve $=\int_{0}^{\varepsilon_{c c}} \sigma_{c} \cdot d \varepsilon_{c c}=\alpha \cdot f_{c}^{\prime} \cdot \varepsilon_{c c}$

Solving for the mean stress factor yields:

$\alpha=\frac{\int_{0}^{\varepsilon_{c c}} \sigma_{c} \cdot d \varepsilon_{c c}}{f_{c}^{\prime} \cdot \varepsilon_{c c}}$

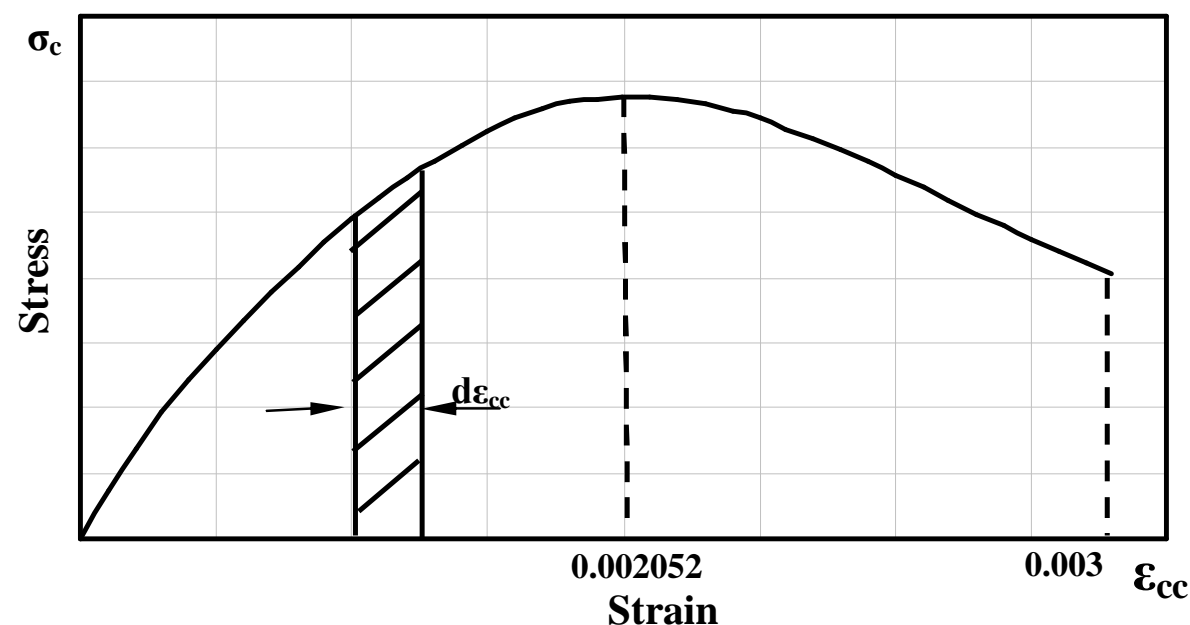

Figure (8): Integration of Concrete Stress-Strain Curve

By substituting equations (1) into (12) and solving for the mean stress factor, the results are the following equation:

$\alpha=-80334 \times\left(\varepsilon_{c c}\right)^{2}+488.25 \times\left(\varepsilon_{c c}\right)$

The concrete compressive force (FC) acts at the centroid of the compression zone, which is defined as being a distance $\square \mathrm{c}$ below the top of the beam (usually a value more than 0.35). The centroid factor $(\square)$ is calculated with the first moment of area under a portion of the concrete stress-strain curve. Taking the first moment of area $\left(\mathrm{m}_{\mathrm{a}}\right)$ about the origin yields:

$m_{a}=A_{c} \cdot \varepsilon_{\text {center }}$

Where, $\mathrm{A}_{\mathrm{c}}=$ the area under the stress-strain curve

$\square_{\text {center }}=$ the strain at the centroid of the area under the stress-strain curve

The strain at the centroid of the area ( $\square$ center $)$ can be defined as:

$\varepsilon_{\text {center }}=(1-\gamma) \varepsilon_{c c}$

By substituting equation (15) and the area under the stress-strain curve, as given in equation (11), into equation (14) yields: 
$m_{a}=\left[\int_{0}^{\varepsilon_{c c}} \sigma_{c} \cdot d \varepsilon_{c c}\right](1-\gamma) \varepsilon_{c c}$

Also, the first moment of area can be defined as,

$m_{a}=\int_{0}^{\varepsilon_{c c}} \sigma_{c} \cdot \varepsilon_{c c} \cdot d \varepsilon_{c c}$

After equating (16) and (17), and solving for the centroid factor,

$$
\gamma=1-\frac{\int_{0}^{\varepsilon_{c c}} \sigma_{c} \cdot \varepsilon_{c c} \cdot d \varepsilon_{c c}}{\varepsilon_{c c} \int_{0}^{\varepsilon_{c c}} \sigma_{c} \cdot d \varepsilon_{c c}}
$$

Next, by substituting (1) into (18) and integrating, the centroid factor is as follows:

$$
\gamma=-2 \times 10^{9}\left(\varepsilon_{c c}\right)^{4}+2 \times 10^{7}\left(\varepsilon_{c c}\right)^{3}-40851\left(\varepsilon_{c c}\right)^{2}+49.124\left(\varepsilon_{c c}\right)+0.3366
$$

The depth of the neutral axis from the extreme compression fiber (c) is obtained from the equilibrium of the internal forces of the beam. The total compressive forces are equal to the total tensile forces,

$$
F_{c c}+F_{s c}-F_{s t}-F_{f}-F_{c t}=0
$$

Rewriting Equation (20) in terms of stresses gives

$$
\alpha \cdot c \cdot b \cdot f_{c}^{\prime}+A_{s c} \cdot \sigma_{s c}-A_{s t} \cdot \sigma_{s t}-A_{f} \cdot \sigma_{f}-\left(\frac{b}{2}\right) \cdot(h-c) \cdot \sigma_{c t}=0
$$

Where, $\sigma_{\mathrm{ct}}=$ tensile stress of concrete at bottom face.

Using the stress-strain relationships for steel and FRP, this equation becomes

$$
\begin{aligned}
& \alpha \cdot c \cdot b \cdot f_{c}^{\prime}+A_{s c} \cdot E_{s} \cdot \varepsilon_{s c}-A_{s t} \cdot E_{s} \cdot \varepsilon_{s t}-A_{f} \cdot E_{f} \cdot \varepsilon_{f}- \\
& \frac{b}{2} \cdot(h-c) \cdot E_{c} \cdot \varepsilon_{c t}=0
\end{aligned}
$$

Before the concrete has cracked or the tensile steel has yielded, using Equations (6),(7), (8), and (9), Equation (22) becomes

$$
\begin{aligned}
& \alpha . c . b \cdot f_{c}^{\prime}+A_{s c} \cdot E_{s} \cdot \varepsilon_{c c} \cdot\left[1-\frac{d^{\prime}}{c}\right]-A_{s t} \cdot E_{s} \cdot \varepsilon_{c c} \cdot\left[\frac{d_{s}}{c}-1\right]- \\
& A_{f} \cdot E_{f} \cdot \varepsilon_{c c} \cdot\left(\frac{d_{f}}{c}-1\right)-\frac{b}{2} \cdot(h-c) \cdot E_{c} \cdot \varepsilon_{c c} \cdot\left(\frac{h}{c}-1\right)=0
\end{aligned}
$$


Once the tensile stress in the extreme bottom tensile fiber of the concrete exceeds the tensile strength of concrete in flexure, the concrete in tension cracks. The tensile strength of concrete in flexure is $f_{t}^{\prime}=\mathbf{0 . 5} \times \sqrt{f_{c}^{\prime}}$ (11). Once the section is cracked, all concrete below the neutral axis is neglected.

After the concrete has cracked in tension, Equation 23 becomes

$$
\begin{aligned}
& \alpha \cdot c \cdot b \cdot f_{c}^{\prime}+A_{s c} \cdot E_{s} \cdot \varepsilon_{c c} \cdot\left[1-\frac{d^{\prime}}{c}\right]-A_{s t} \cdot E_{s} \cdot \varepsilon_{c c} \cdot\left[\frac{d_{s}}{c}-1\right] \\
& -A_{f} \cdot E_{f} \cdot \varepsilon_{c c} \cdot\left[\frac{d_{f}}{c}-1\right]=0
\end{aligned}
$$

When the tensile steel has yielded, Equation (24) becomes

$$
\begin{aligned}
& \alpha . b . c \cdot f_{c}^{\prime}+A_{s c} \cdot E_{s} \cdot \varepsilon_{c c} \cdot\left[1-\frac{d_{s c}}{c}\right]-A_{s t} \cdot\left[f_{y}+E_{s t}\left(\varepsilon_{c c}\left(\frac{d_{s}}{c}-1\right)-\frac{f_{y}}{E_{s}}\right)\right] \\
& -A_{f} \cdot E_{f} \cdot \varepsilon_{c c} \cdot\left[\frac{d_{f}}{c}-1\right]=0
\end{aligned}
$$

After the GFRP Sheet has exceed the ultimate tensile strength, Equation (25) become

$$
\begin{aligned}
& \alpha . b . c \cdot f_{c}^{\prime}+A_{s c} \cdot E_{s} \cdot \varepsilon_{c c} \cdot\left[1-\frac{d_{s c}}{c}\right]-A_{s t} \cdot\left[f_{y}+E_{s t}\left(\varepsilon_{c c}\left(\frac{d_{s}}{c}-1\right)-\frac{f_{y}}{E_{s}}\right)\right] \\
& -A_{f} \cdot f_{y f}=0
\end{aligned}
$$

Equations (23), (24), (25) and (26) are quadratic equations in terms of c that can be solved in closed form. The strain in the top compression fiber of the concrete, $\varepsilon \mathrm{cc}$, is chosen to be a certain value, and the magnitude factor $\alpha$ and $\gamma$ are calculated based on the chosen value of $\varepsilon \mathrm{cc}$. The depth to the neutral axis can then be found by using either Equation (23), (24), (25) or (26), depending on whether or not the tensile concrete has cracked or if the tensile concrete has cracked and the tensile steel has yielded. The moment on the cross section (Mn) can be found by taking the sum of moments about the concrete force resultant.

Equation (27) is used when the tensile concrete has not cracked, and Equation (28) is used when the tensile concrete has cracked, whether the tensile steel has been yielded or not.

$$
\begin{aligned}
& M_{n}=A_{s t} \cdot \sigma_{s t} \cdot\left(d_{s}-\gamma c\right)+A_{f} \cdot \sigma_{f} \cdot\left(d_{f}-\gamma c\right)+A_{s c} \cdot \sigma_{s c} \cdot\left(\gamma c-d^{\prime}\right)+ \\
& \left(\frac{b}{2}\right) \cdot \sigma_{c t} \cdot(h-c) \cdot\left(h-\gamma c-\left(\frac{h-c}{3}\right)\right)^{2} \\
& M_{n}=A_{s t} \cdot \sigma_{s t} \cdot\left(d_{s}-\gamma c\right)+A_{f} \cdot \sigma_{f} \cdot\left(d_{f}-\gamma c\right)+A_{s c} \cdot \sigma_{s c} \cdot\left(\gamma c-d^{\prime}\right)
\end{aligned}
$$

The curvature of the beam is determined by considering a small element, $\mathrm{dx}$, subjected to pure bending moments as shown in Figure(9) (12). The radius of curvature (R), the neutral axis from the extreme compression fiber, the concrete strain of the extreme compression fiber, and the tension steel strain, all change by increasing the loading. Assuming plane sections remain plane, the rotation between the ends of the element can be described by the following: 


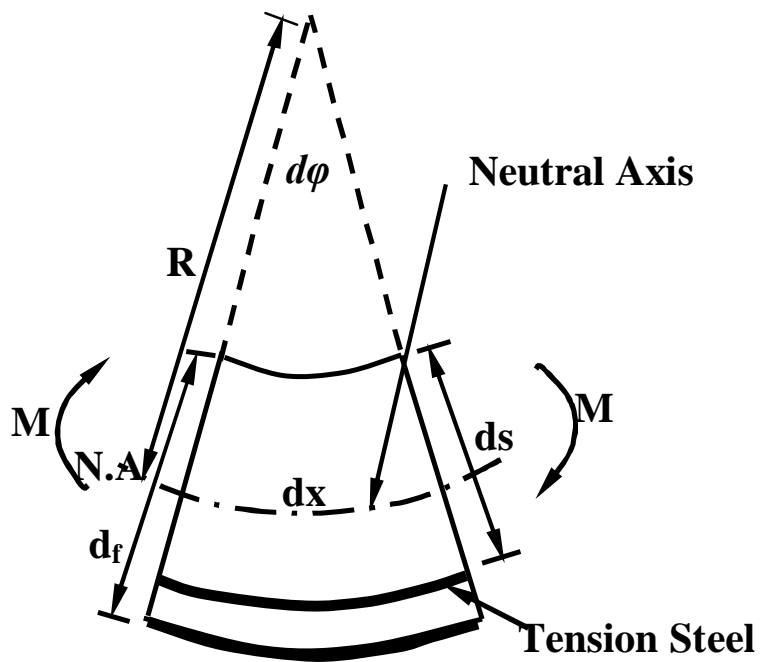

Section

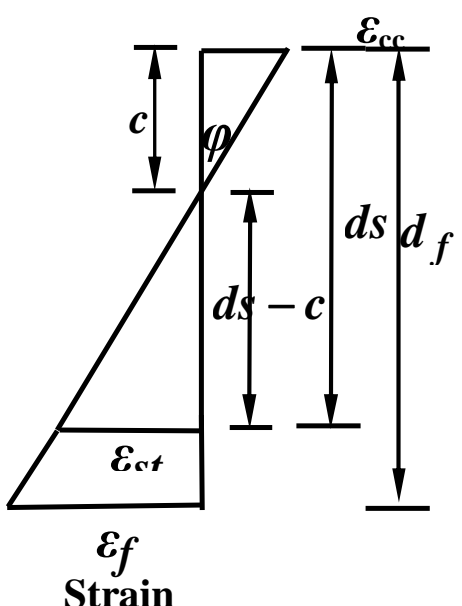

Distribution

Figure (9): Rotation of Flexural Member

$$
\begin{aligned}
& \frac{d x}{R}=\frac{\varepsilon_{c c} \cdot d x}{c}=\frac{\varepsilon_{s t} \cdot d x}{d_{s}-c} \\
& \frac{1}{R}=\frac{\varepsilon_{c c}}{c}
\end{aligned}
$$

Since curvature $(\square)$ is the inverse of the radius of curvature, it is defined by the following equation:

$\varphi=\frac{\varepsilon_{c c}}{c}$

Furthermore, the midspan deflection of the beam can be determined from a curvature (M/EI) diagram of the beam using the moment-area method. Assuming the beam rests on simple supports and four points loading is applied, the moment of area under the curvature diagram between midspan and about the support yields the following equation for midspan deflection:

$$
\Delta=\frac{256 \cdot M \cdot L^{2}}{2400 \cdot E \cdot I}=\frac{256 \cdot \varphi \cdot L^{2}}{2400}
$$

Where, $\square=$ centerline deflection of the beam

$\dot{\mathrm{L}}=$ distance between supports of the beam

\section{Test Results and Discussions}

The experimental load/midspan deflection curves for beams RB1-0, RB2-1-B, RB3-2$B$ and RB4-3-B are shown in Fig (10). Although the initial stiffness of the beam remains unchanged, the stiffness has changed considerably after cracking. The increase in stiffness is proportional to the sheet thickness. As shown in Table (3) glass wrapping increased the ultimate strength of reinforced concrete beams, The percentage increase in (Load-Carrying Capacity) through wrapping is a function of the number of longitudinal Glass layer up to certain thickness of the wrap.

Crack Pattern and Failure Modes: The crack patterns at collapse for the tested beams are shown in Fig. (11) and Fig. (12). The control beam exhibited widely spaced and lesser number of cracks compared to strengthened beam. The strengthened beams have also shown cracks at relatively closer spacing. This shows the enhanced concrete confinement due to the 


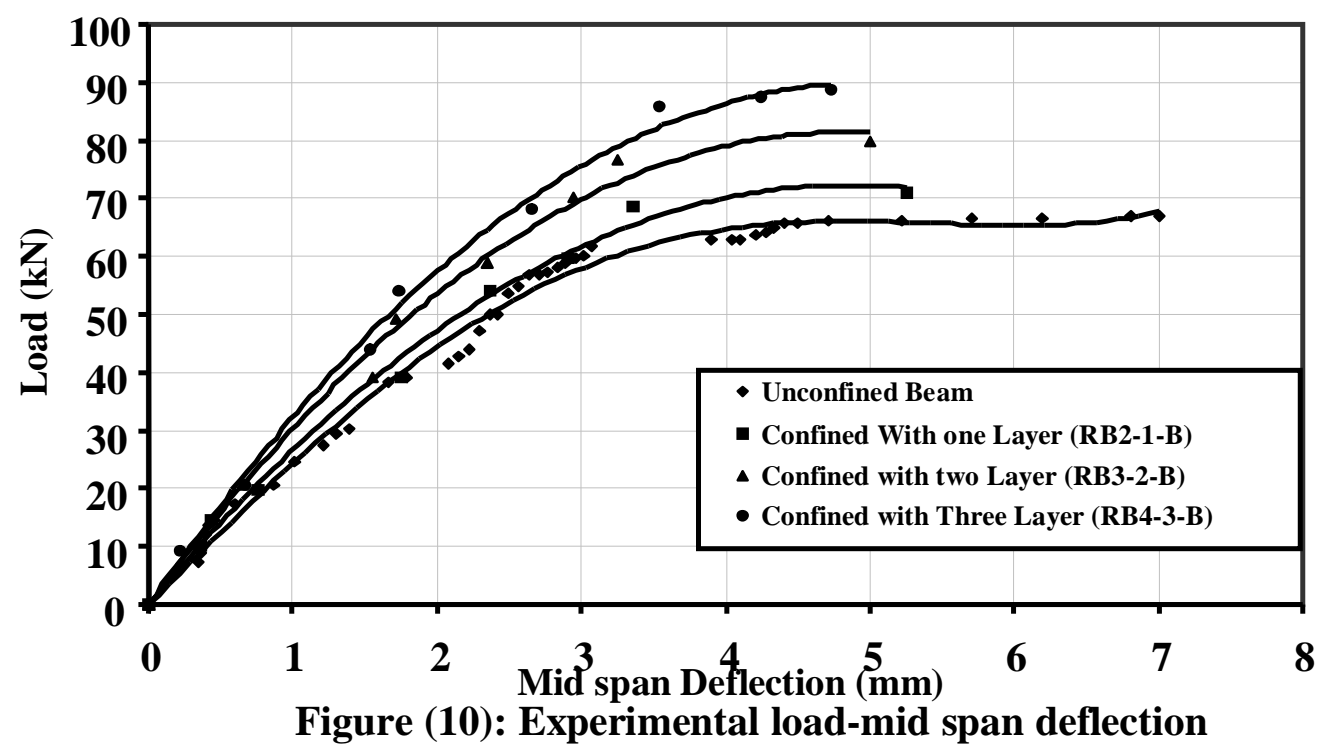

GFRP sheet. The debonding has taken place at the end of beams (RB3-2-B) and (RB4-3-B) toward the center due to high stress concentration at the concrete-FRP interface as shown Fig (12). High stress concentrations around flexural cracks may promote debonding(11), however, such stress concentrations diminish rapidly with propagation of debonding, resulting in a limited debonded area (2) that occurred in beam (RB2-1-B) as can be seen in Fig. (13).

Table (3): Effect Strengthening R/C Beam with GFRP Sheets on Yielding and Failure Load

\begin{tabular}{|l|c|c|c|l|}
\hline \multirow{2}{*}{ Specimen } & \multicolumn{2}{|c|}{ Load } & $\begin{array}{c}\text { \%Increase } \\
\text { in Failure } \\
\text { Load }\end{array}$ & \multicolumn{1}{|c|}{ Mode of Failure } \\
\cline { 2 - 5 } RB1-0 & 59 & 72.6 & $\begin{array}{c}\text { Failure } \\
\text { Load(kN) }\end{array}$ & $\begin{array}{l}\text {-Yield of Steel followed by } \\
\text { crushing of concrete. }\end{array}$ \\
\hline RB2-1-B & 68.6 & 80.4 & 10.7 & $\begin{array}{l}\text {-Yield of Steel followed by } \\
\text { Rupture of GFRP Sheets. }\end{array}$ \\
\hline RB3-2-B & 76 & 88.7 & 22.2 & $\begin{array}{l}\text {-Yielding of Steel followed } \\
\text { by debonding(Separation) of } \\
\text { GFRP Sheet. }\end{array}$ \\
\hline RB4-3-B & 87.5 & 105.4 & 45.2 & $\begin{array}{l}\text {-Yield of Steel followed by } \\
\text { separation of GFRP Sheet. }\end{array}$ \\
\hline
\end{tabular}

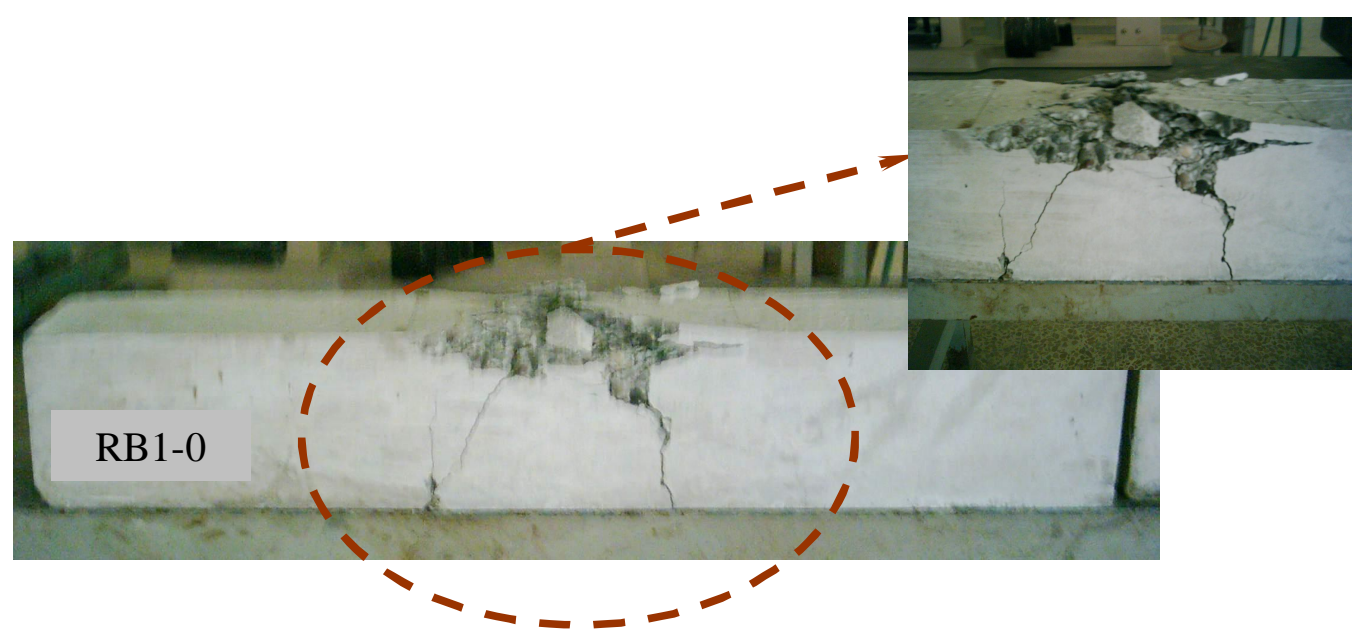

Figure (11): Failure mod of Beam (RB1-0) 


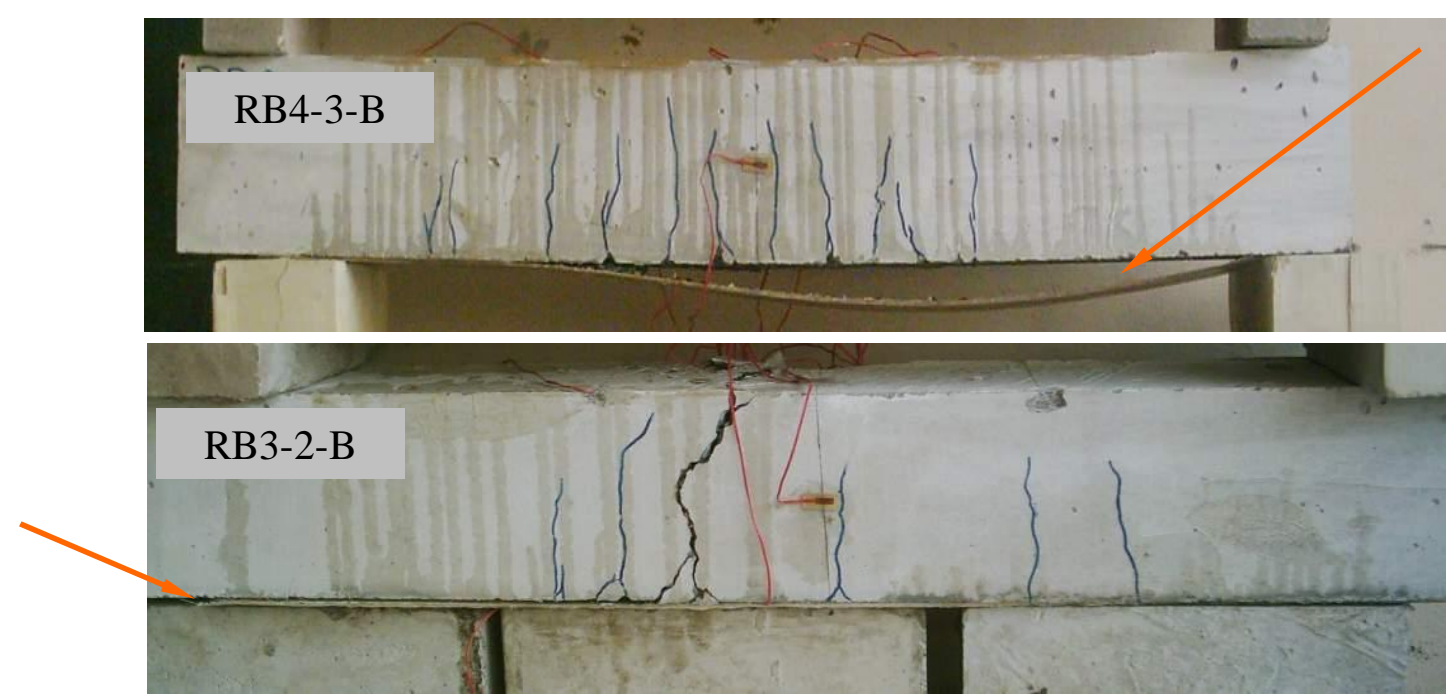

Figure (12): Failure mod of Beams (RB3-2-B) and (RB4-3-B)

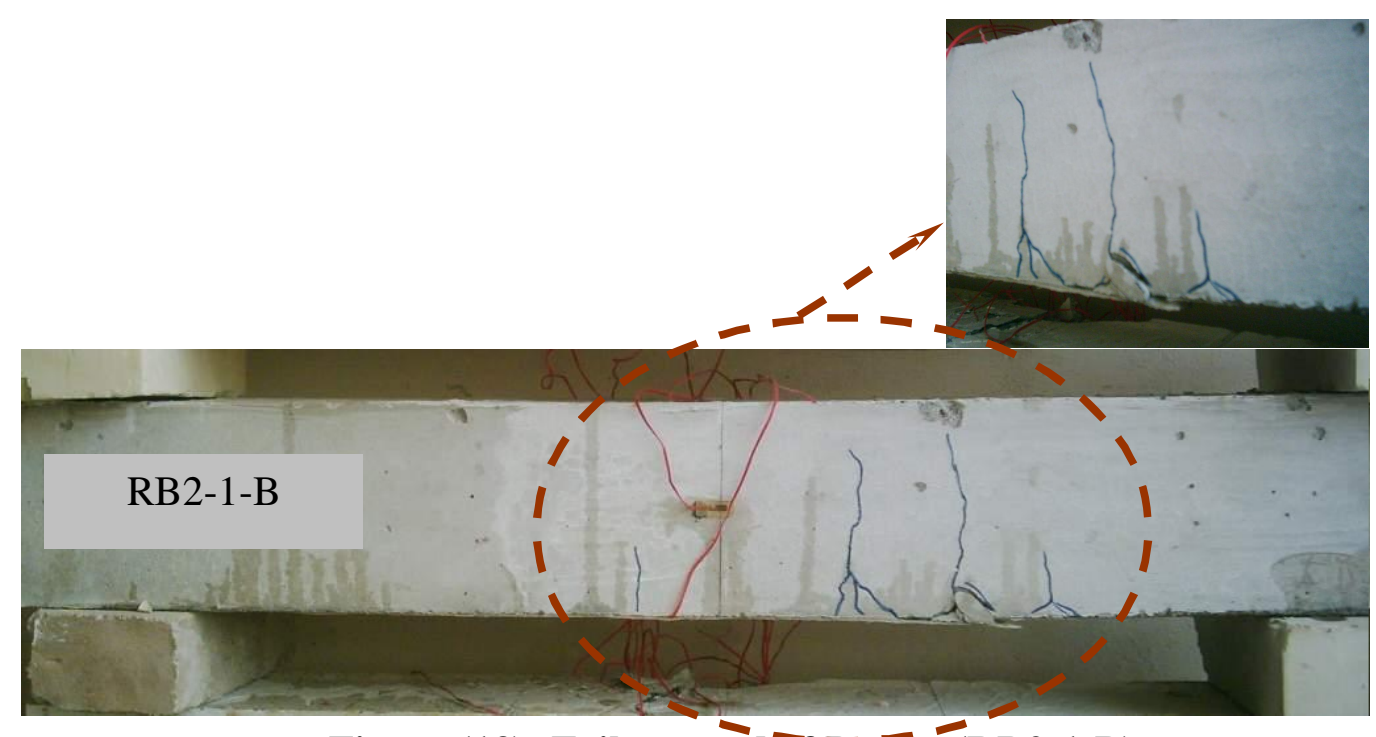

Figure (13): Failure mod of Бeams (RB2-1-B)

\section{Comparison of Analytical Calculations with Experimental Results:}

Steel Stress: It is seen that at a given load level, rebar stresses and deflections were found to be less in Glass-wrapped beams compared to rebar stresses of unreinforced beams. Yielding of steel bars occurred at about (48.3\%) higher load in beam wrapped with three layers as compared to beams without wrapping as seen in table(3).

Failure load Deflection: Comparison of the experimental and predicted load-deflection curve for the (RB1-0), (RB2-1-B),(RB3-2-B) and (RB4-3-B) beams are shown in Fig.(14-17) respectively. It can be seen from these figures that the model has predicted the load deformation behavior with reasonable accuracy. The analytical procedure underestimates the failure loads. The model under-predicted the failure load by about (20\%) as seen in table (4). 


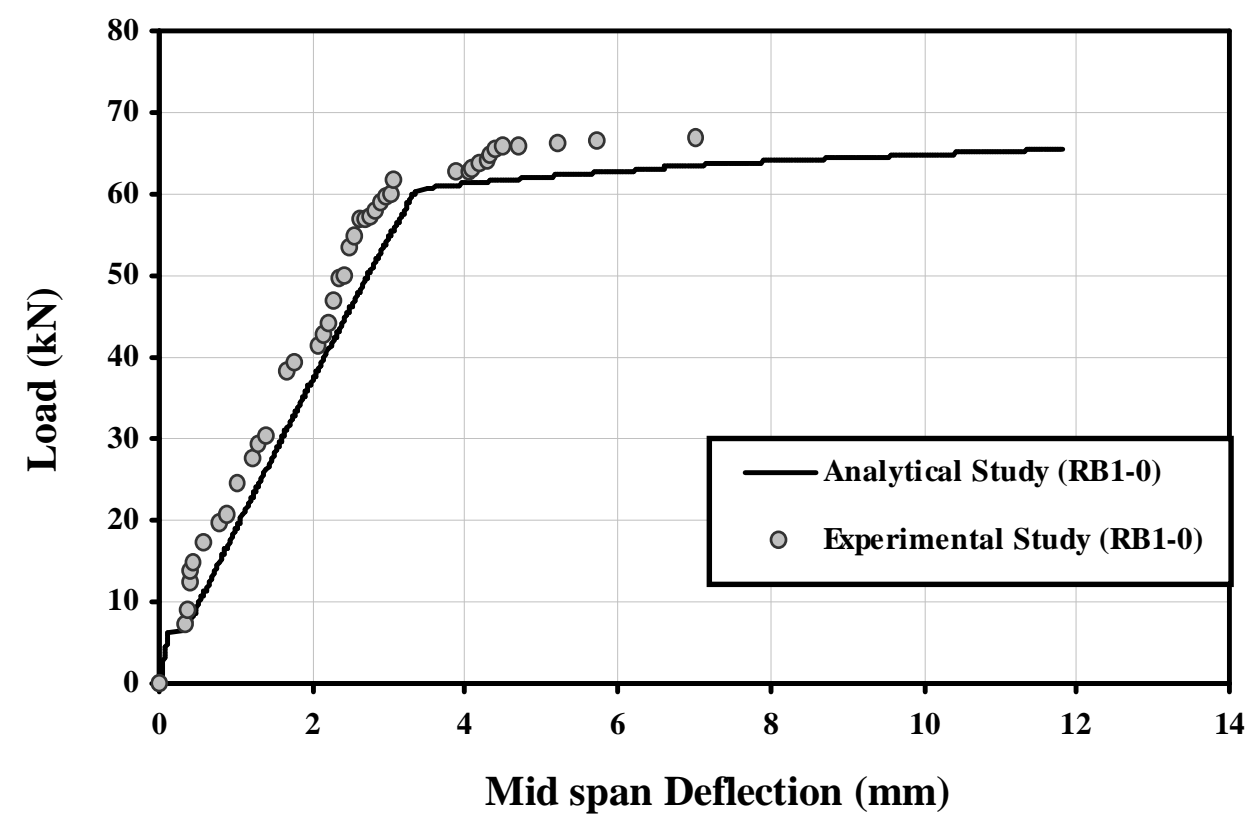

Figure (14): Numerical and Experimental Load/Deflection Curve of Control Beam

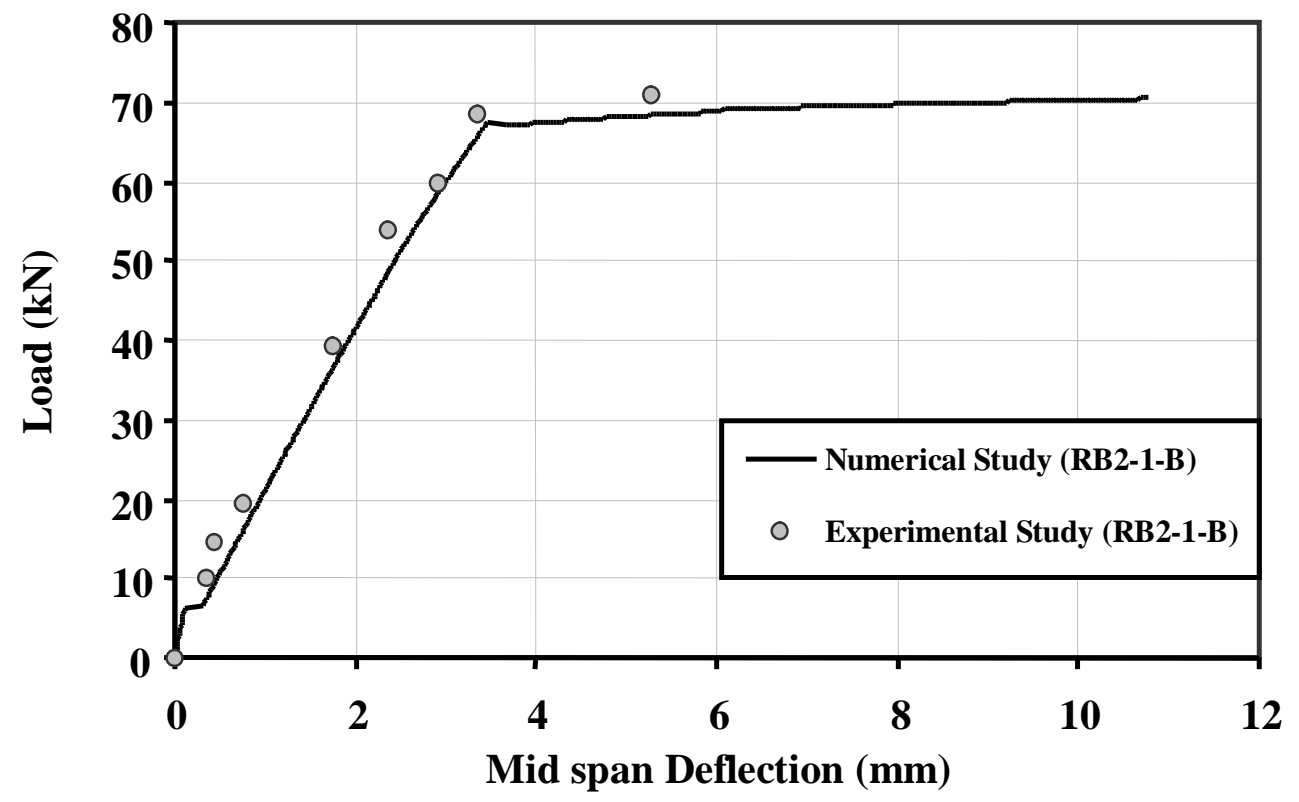

Figure (15): Numerical and Experimental Load/Deflection Curve of Beam Strengthened with One Layer of GFRP Sheets 


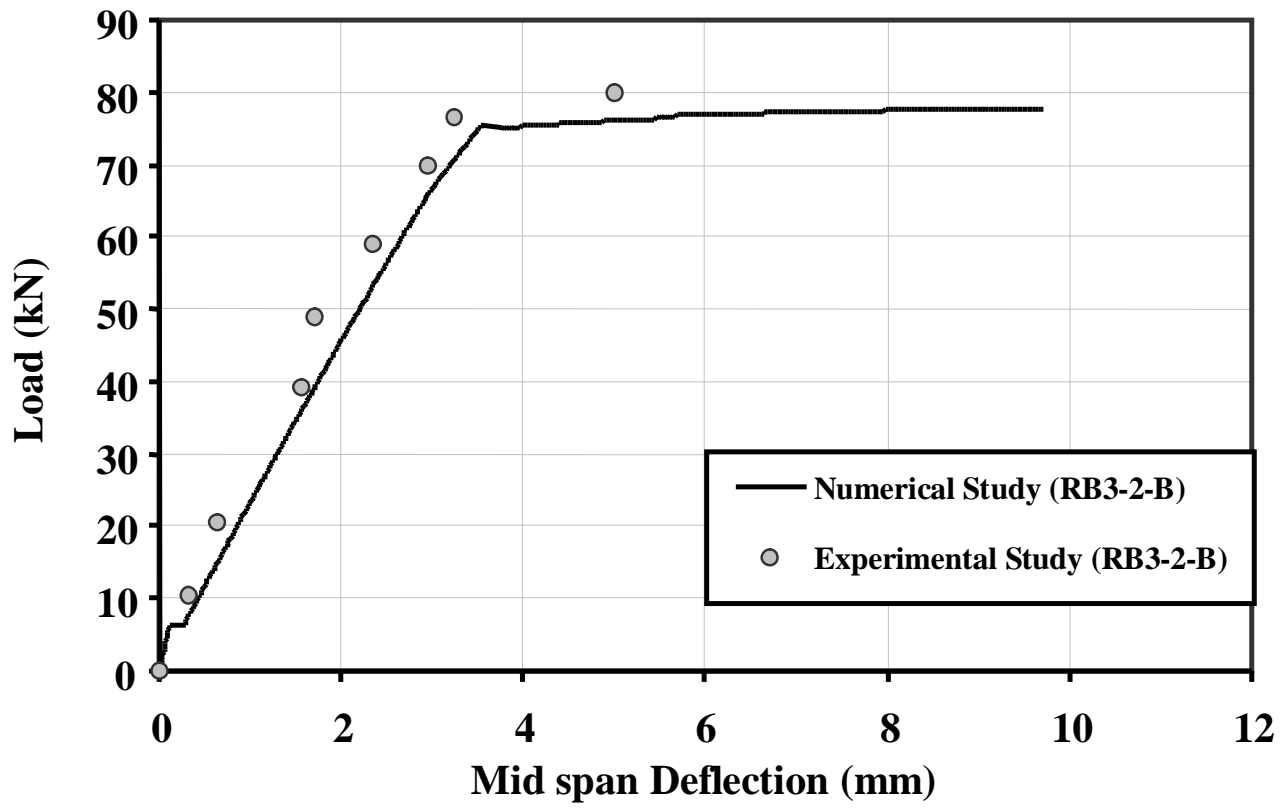

Figure (16): Numerical and Experimental Load/Deflection Curve of Beam Strengthened with Tow Layers of GFRP Sheets

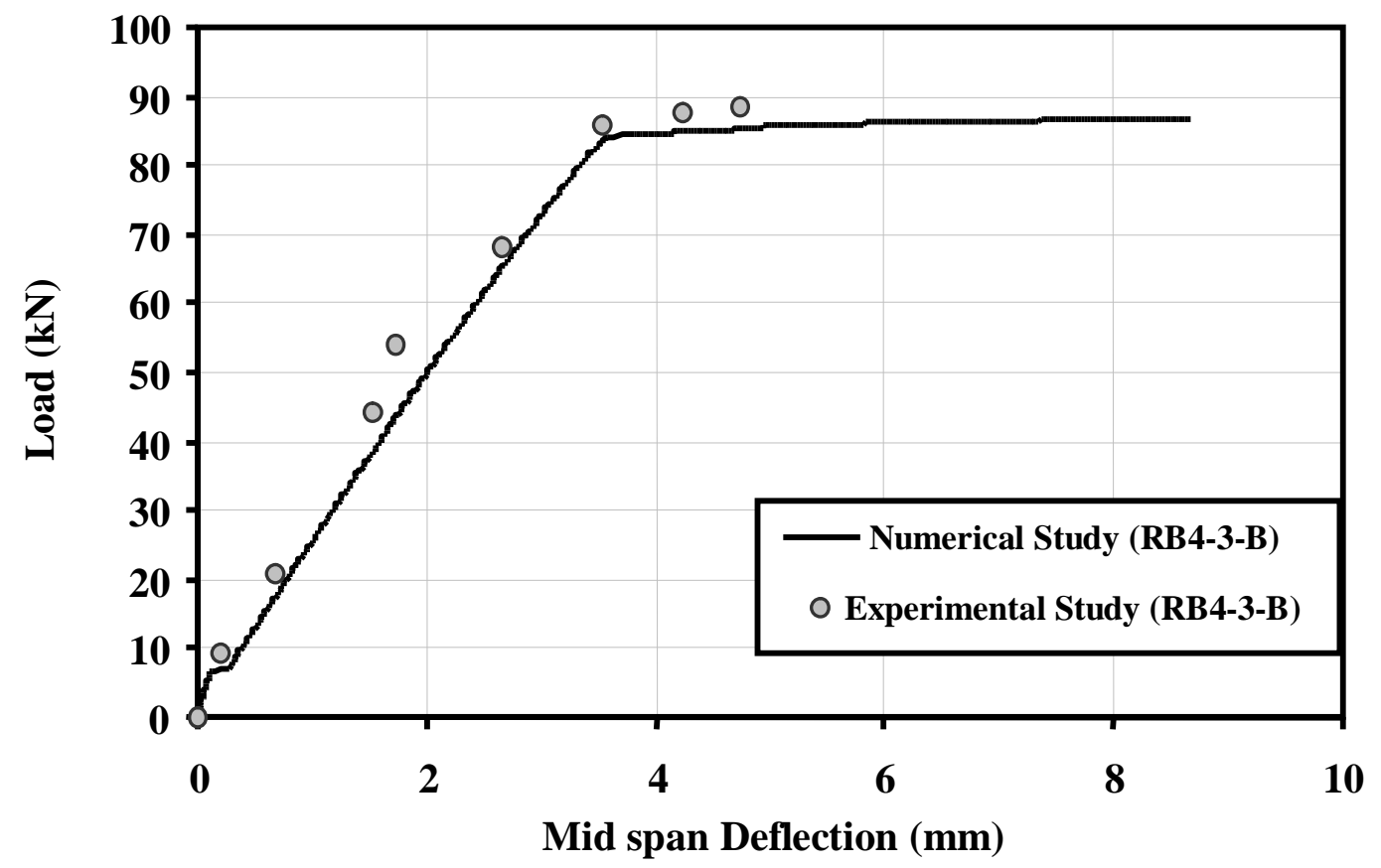

Figure (17): Analytical and Experimental Load/Deflection Curve of Beam Strengthened with Three Layers of GFRP Sheets 


\section{Al-Rafidain Engineering $\quad$ Vol.17 $\quad$ No.6 $\quad$ Dec. 2009}

Table (4): Comparison of Analytical Failure load with Experimental Failure Load of R/C Beams Strengthened with GFRP Sheets

\begin{tabular}{|c|c|c|c|c|c|c|}
\hline Specimen & $\begin{array}{c}\text { Experimental } \\
\text { Yield } \\
\text { Load(kN) } \mathrm{P}_{\text {ye }}\end{array}$ & $\begin{array}{c}\text { Analytical } \\
\text { Yield } \\
\text { Load }(\mathrm{Kn}) \\
\mathrm{P}_{\text {ya }}\end{array}$ & $\mathrm{P}_{\text {ye }} / \mathrm{P}_{\text {ya }}$ & $\begin{array}{c}\text { Experimental } \\
\text { Failure Load } \\
(\mathrm{kN}) \mathrm{P}_{\text {ue }}\end{array}$ & $\begin{array}{c}\text { Analytical } \\
\text { Failure } \\
\text { Load(kN) } \mathrm{P}_{\text {ua }}\end{array}$ & $\mathrm{P}_{\text {ue }} / \mathrm{P}_{\text {ua }}$ \\
\hline RB1-0 & 59 & 59.1 & 1 & 72.6 & 65.5 & 1.1 \\
\hline RB2-1-B & 68.6 & 67.1 & 1.02 & 80.4 & 70.4 & 1.14 \\
\hline RB3-2-B & 76 & 73.3 & 1.04 & 88.7 & 77.8 & 1.14 \\
\hline RB4-3-B & 87.5 & 82.8 & 1.06 & 105.4 & 86.7 & 1.2 \\
\hline
\end{tabular}

\section{Conclusions}

1-Strength and stiffness properties of Glass fiber reinforced sheets resulted in improved performance of flexural Strength of concrete members.

2- Percentage increase in ultimate strength capacity of wrapped concrete beams is function of number of longitudinal layers of glass fabric.

3-Two of the beams (RB3-2-B) and (RB4-3-B) failed by debonding of GFRP sheets due to high stress concentration at beam ends, to preventing that mode of failure a U-Strips maybe provided to gain better anchoring mechanism.

4-The cracks at ultimate load of strengthened beam were more in number compared with that of the control beam indicating clearly the composite action due to GFRP sheets.

5 -The adopted analytical procedure can be used for the design of concrete beams Strengthened/Retrofitted with GFRP sheets.

\section{References}

1- Khalifa,A., Gold, W.J., Nanni, A. and Abdel Aziz, M.I., "Contribution of Externally Bonded FRP to Shear Capacity of R/C Flexural Members", Journal of Composites for Construction, Vol.2. No.4, November, 1998, pp.195-202.

2- Buyukozturk, O., Gunes, O. and Karaca, E., "Characterization and Modeling of Debonding in R/C Beams Strengthened with FRP Composites", $15^{\text {th }}$ ASCE Engineering Conference, Columbia University, New York, June 2-5, 2002.

3- Saadatmanesh, H., and Ehsani, M.R., "RC Beams Strengthened with GFRP Plates.I:Experimental Study", Journal of Structure Engineering, 1991, 117(11), 34173433.

4- Sharif, A., Al-Sulaimani, G.J., Basunbul, I.A., Baluch, M.H., and Ghaleb, B.N., "Strenthening of Initially Loaded Reinforced Concrete Beams Using FRP Plates", ACI Structural Journal, March-April, 160-168.

5- Inaba, C.M., Warren, G.E., and Inaba, C., "Reinforced concrete beams strengthened with CFRP Sheets", Proc., Non-Metallic (FRP) Reinforcements for Concrete Structure, FRPCS-2, $2^{\text {nd }}$ International RiLEM Symposium Proc. L. Taerwe, ed., Ghent, Belgium, 1995.

6- Meier, U., Deuring, M., Meier, H., and Shwegler, G., "Strengthening of structures with CFRP laminates: research and application in Switzerland", Proc., $1^{\text {st }}$ Int. Conf. on Advanced Compos. Mat. In Bridges and Struct., Canadian Soc. of Civ. Eng., Sherbrooke, Quebec, 1992, 243-251.

7- Ritchie, P. A., Thomas, D.A., Lu, L.W., and Connelly, G.M., "External reinforcement of concrete beams using fiber glass reinforced plastics", ACI Struct. J., 1991, 88(4), 490500 . 
8-Saadatmanesh, H., and Ehsani, M.R., "Fiber composite plates can strengthen be ams", ACI Concrete International, 1990, 12(3), 65-71.

9- An, W., Saadatmanesh, H., and Ehsani, M.R., "RC Beams Strengthened with FRP Plates.II: Analysis and Parametric Study", ASCE Journal of Structural Engineering, Vol.117, pp.3434-3455, November 1991.

10- Al-Sulayfani, B.J., "Contribution $\mathrm{AL}^{\prime}$ etude Du Comportement Des Ossatures En Beton Arme Sous Sollicitations Cycliques Analyse Non-Lineaire Globale", Docterue De L'Universite De Nantes, Sepecialite Genie Civil, 1986.

11- Ebrahim, T.M., Arther, N.H. and Floyd, S.O., "Biaxial Stress-Strain Relationship for Concrete", Magazine of Concrete Research, Vol. 31, No. 109, December., 1979.

12- Park, R. and Paulay, T. Reinforced Concrete Structures, John Wiley and Sons, New York, 1975.

13- Leu ng, C.K.Y., :Delamination Failure Aspects Oof Cncrete Beams Retrofitted with a Bonded Plate", Journal of Materials in Civil Engineering, 2002, pp.106-113. 